\title{
Relationship between Locus of Control and Academic Achievement of Secondary School Students in Abia State
}

\author{
Onyinyechi Rita Chinedu, Chikaodili Benedine Nwizuzu
}

Department of Educational Psychology, Chukwuemeka Odumegwu Ojukwu University, Igbariam Campus, Igbariam, Nigeria Email: cnwizuzu@yahoo.com

How to cite this paper: Chinedu, O.R. and Nwizuzu, C.B. (2021) Relationship between Locus of Control and Academic Achievement of Secondary School Students in Abia State. Journal of Analytical Sciences, Methods and Instrumentation, 11, 15-22. https://doi.org/10.4236/jasmi.2021.112002

Received: April 20, 2021

Accepted: June 27, 2021

Published: June 30, 2021

Copyright (อ 2021 by author(s) and Scientific Research Publishing Inc. This work is licensed under the Creative Commons Attribution International License (CC BY 4.0).

http://creativecommons.org/licenses/by/4.0/

(c) (i) Open Access

\begin{abstract}
The study intended to determine the relationship between locus of control and academic achievement of secondary school students. Some students have been observed to achieve higher while some achieve lower even after being exposed to the same subject matter by the same instructor. The objective of the study was to determine if locus of control correlated with academic achievement of students as moderated by gender and school-type. The study was anchored on attribution theory. The study adopted a correlational research design. A total of 388 SS3 students in Aba Education zone were selected using purposive and simple random sampling techniques. Instruments for data collection were an adopted LOC scale and students' exam scores in Mathematics, English and CRS. To determine the reliability of the instrument, Kuder-Richardson reliability test (KR-20) was employed and an overall coefficient of 0.76 was obtained for LOC scale. Data were analyzed using Pearson Product Moment Correlation Coefficient. Results showed significant relationship between locus of control and academic achievement of male students. Results also showed significant relationship between locus of control and academic achievement of public school students. Based on the findings, it was recommended that school authority should encourage good performance by rewarding students with excellent performance, because when good behaviour is rewarded, the individual is motivated to do better. Also, government should also provide the schools with necessary infrastructures that would make teaching and learning very interesting.
\end{abstract}

\section{Keywords}

Locus of Control, Attribution, Academic Achievement, Motivation 


\section{Introduction}

Locus of control was introduced by Rotter in 1966 to explain how we assign causes to our successes or failures. Khan [1] defined locus of control as the type of attributions we make for our successes or failures in task. The important thing about attribution is that they reflect personal beliefs about the sources or causes of life events and outcomes. Locus of control therefore, is the kind of excuse one makes concerning life occurrences. Locus means location, in other words, location of control. It implies that in every individual, control is located somewhere, either within the individual or outside the individual, hence, internal and external locus of control. Schunk [2] believed also that locus of control influences students' motivation that students who believed they had little control over academic work outcomes have low expectations for success and display low motivation to succeed. That is to say, the kind of belief a student has about the cause of his successes and failures in school task can increase or decrease his motivation for studying and doing academic work.

\section{Statement of the Problems}

Every government advocates improved standard of education, but when the academic achievement of students does not reflect the desire of the government, then the situation becomes a source of concern to all. Experience shows that while some students are more studious and goal-oriented and consequently achieve higher academically, others have been observed to have low interest in their academic work with resultant low academic achievement. Though students may be taught the same subject-matter, exposed to the same learning material by same instructor, they perform and achieve differently and their levels of achievement vary significantly. What could be responsible for this difference in achievement?

\section{Objectives of the Study}

1) To determine the relationship between locus of control and academic achievement of male secondary school students.

2) To ascertain the relationship between locus of control and academic achievement of female secondary school students.

3) To examine the relationship between locus of control and academic achievement of students in public secondary schools.

4) To describe the relationship between locus of control and academic achievement of students in private secondary schools.

\section{Hypotheses}

1) There is no significant relationship between locus of control and academic achievement of male students.

2) There is no significant relationship between locus of control and academic achievement of female students. 
3) There is no significant relationship between locus of control and academic achievement of students in public secondary schools.

4) There is no significant relationship between locus of control and academic achievement of students in private secondary schools.

\section{Literature Review}

Locus of control is a personality characteristic of an individual that determines the degree to which such an individual believes that he or she is in control of life events. Locus of control can also be described as an individual's generalized expectations concerning where control over subsequent events or antecedents resides. In other words, who or what is responsible for what happens [1]. Locus of control can be internal or external. When an individual feels that his success or failure is as a result of his action or inaction, such a person is internally controlled. However, when an individual feels that his success or failure is as a result of actions or inactions of significant others, he is externally controlled. If a student attributes a high score on a test to his ability, then the locus is internal. If a student attributes allow score to test difficulty or to hard teacher, then the attribution is external. Students' academic achievement plays an important role in producing quality graduates who will become future leaders. When quality graduates are produced, the nation can hope to have responsible citizens who in turn will help to improve the society's economic and social development [3] [4]. Ganai and Mir [5] defined academic achievement as excellence in all academic disciplines in class as well as co- curricular activities which includes excellence in sporting events behaviour, confidence, communication skills, punctuality, arts, culture and the like which can be achieved only when an individual is well adjusted. According to Saeed and Zyngier [6] student engagement in learning is not only an end in itself but it is also a means to the end of students achieving sound academic outcomes. Motivation is seen as a pre-requisite and a necessary element for student engagement in learning. Although some learning can occur with little or no motivation, most learning is motivated. Motivated students attend to instruction and engage in such activities as rehearsing information, relating it to previously acquired knowledge, and asking questions. Rather than quit when they encounter difficulty, motivated students expend greater effort. Motivation engages students in activities that facilitate learning [2].

According to attribution theory, the explanations that people tend to make to explain success or failure can be analyzed in terms of three sets of characteristics: locus (being either internal or external), stability (being either stable or unstable) and controllability (being either controllable or uncontrollable). Hasan and Khalid [7] observed that individuals tend to do causal analysis of their behaviour consciously. These authors believe that people attribute their achievements or failures to internal factors such as intelligence or lack of it, hard work or laziness, ability or inability and to external factors such as good or bad luck, easy or tough rules of examination system or biased marking and so on. Rinn, Boazman, Jackson and Barrio [8] believed that whether a person attributes success and failure 
to internal factors or to external factors, has a way of influencing the person's response to situations.

\section{Research Methods}

The study adopted a correlational research design. The study population was made up of all SS3 students in Aba Education zone, Abia state. Purposive sampling technique was used to select 400 students while simple random technique was employed in selecting respondents from public and private schools that completed the questionnaire. Instruments for data collection was an adopted Locus of Control scale by Rotter [9] and students' average scores in terminal exams in Mathematics, English and CRS. For measuring the internal consistency, Kuder-Richardson reliability test (KR-20) was applied using the SPSS software to ensure reliability on an alpha level of 0.05 . An overall co-efficient of 0.758 was obtained for LOC-Scale. Return rate for the instrument was 97\% (388). Data was analyzed using Pearson Product Moment Correlation Co-efficient.

\section{Data Presentation and Interpretation (Table 1)}

A Pearson Product-Moment Correlation Coefficient was computed to assess the relationship between the LOC and academic achievement students. Result revealed a positive correlation between LOC male and academic achievement, $r=$ $0.657, \mathrm{n}=196, \mathrm{p}=0.000$. Therefore, there is a strong, positive correlation between LOC and Academic achievement of male students. There is a positive correlation between LOC female and academic achievement, $\mathrm{r}=0.791, \mathrm{n}=192$, $\mathrm{p}=0.000$. Thus, there is a strong, positive correlation between LOC and academic achievement of female students. Result showed a positive correlation between LOC public and academic achievement, $\mathrm{r}=0.762, \mathrm{n}=188, \mathrm{p}=0.000$. Thus, there is a strong, positive correlation between LOC and academic achievement of students in public secondary schools. There is also, a positive correlation between the LOC private and academic achievement, $\mathrm{r}=0.746, \mathrm{n}=$ $200, p=0.000$. Overall, there is a strong, positive correlation between LOC and academic achievement of students in private secondary schools.

\section{Discussions}

Result showed that there is a significant relationship between locus of control and academic achievement of male students. This finding agreed with Kalantarkousheh Mohagheghi and Hosseini [10], Khan [1] who also found a significant positive relationship between locus of control and academic achievement among male students. However, it disagreed with Ghazvini and Khajehpour [11] and Bozorgi [12] who found no significant relationship between locus of control and academic achievement among male students. This contradiction in results may be as a result of other factors other than locus of control that may have impacted their academic performance. Result showed revealed a significant relationship between locus of control and academic achievement of female students. 
Table 1. Relationship between locus of control and academic achievement of male secondary school students.

\begin{tabular}{|c|c|c|c|c|}
\hline & & LOCM Male & Male Achievement & Decision \\
\hline \multirow{3}{*}{ LOC Male } & Pearson Correlation & 1 & 0.657 & \\
\hline & Sig. (2-tailed) & & 0.000 & S \\
\hline & $\mathrm{N}$ & 196 & 196 & \\
\hline \multirow{4}{*}{ Male Achievement } & Pearson Correlation & 0.657 & 1 & \\
\hline & Sig. (2-tailed) & 0.000 & & \\
\hline & $\mathrm{N}$ & 196 & 196 & \\
\hline & & LOC Female & Female Achievement & \\
\hline \multirow{3}{*}{ LOC Female } & Pearson Correlation & 1 & 0.791 & \\
\hline & Sig. (2-tailed) & & 0.000 & S \\
\hline & $\mathrm{N}$ & 192 & 192 & \\
\hline \multirow{4}{*}{ Female Achievement } & Pearson Correlation & 0.791 & 1 & \\
\hline & Sig. (2-tailed) & 0.000 & & \\
\hline & $\mathrm{N}$ & 192 & 192 & \\
\hline & & LOC Public & Public Students Achievement & \\
\hline \multirow{3}{*}{ LOC Public } & Pearson Correlation & 1 & 0.762 & \\
\hline & Sig. (2-tailed) & & 0.000 & S \\
\hline & $\mathrm{N}$ & 188 & 188 & \\
\hline \multirow{4}{*}{ Public Students Achievement } & Pearson Correlation & 0.762 & 1 & \\
\hline & Sig. (2-tailed) & 0.000 & & \\
\hline & $\mathrm{N}$ & 188 & 188 & \\
\hline & & LOC Private & Private Students Achievement & \\
\hline \multirow{3}{*}{ LOC Private } & Pearson Correlation & 1 & 0.746 & \\
\hline & Sig. (2-tailed) & & 0.000 & S \\
\hline & $\mathrm{N}$ & 200 & 200 & \\
\hline \multirow{3}{*}{ Private Students achievement } & Pearson Correlation & 0.746 & 1 & \\
\hline & Sig. (2-tailed) & 0.000 & & \\
\hline & $\mathrm{N}$ & 200 & 200 & \\
\hline
\end{tabular}

Source: Field Survey, 2017. $\mathrm{N}=388$, Level of significance $=0.05, \mathrm{~S}=$ Significant.

The finding was supported by Ghazvini and Khajehpour [11] who reported a significant relationship between locus of control and academic achievement in female students. However, it disagreed with Kalantarkousheh Mohagheghi and Hosseini [10] who found no significant relationship between locus of control and academic achievement of female students. This difference in finding may be due to the fact that females today are realizing that they can control their own destinies and can have greater control over their lives as a way to compensate for 
the traditional female roles of the past. Females today believe that what their male counterparts can do, they (females) can do even better. Result showed also a significant relationship between locus of control and academic achievement of students in public secondary schools.

This finding was supported by Khan and Iqbal [13] and Fakeye [14] who reported a significant relationship between locus of control and academic achievement of male and female students of government schools. The finding however, was contradicted by Mukolwe [15] who found no statistically significant relationship between Locus of control, exam anxiety and academic performance of students in Public secondary schools. This contradiction may have been informed by various factors that have befallen public schools the past [16]. Factors such as inadequate school infrastructures, negligence, unmotivated workforce, lack of reward for good performance, poor monitoring and supervision, etc.

A lot of things may have change in public schools to bring about the difference in findings today. A lot of renovations were on-going in most public schools visited, more qualified teachers are being employed both permanent staff and Npower teachers. All these and more may have impacted on the students' locus of control and academic achievement. Result showed that there is a significant relationship between locus of control and academic achievement of students in private secondary schools. This finding was confirmed by with Khan and Iqbal [13] who also found a relationship between locus of control and academic achievement of male and female students of private schools. It found both sexes equal in their locus of control. This finding implies that students in private schools like their public school counterparts exhibit some level of internal and external locus of control. It showed that locus of control is about the individual and not the school-type.

\section{Conclusion and Recommendations}

Locus of control is important in the academic development of student, because the level of academic achievement at secondary school level may go a long way to determine how far they will go in life. The kind of attribution students make determines the location of their control. A lot of related literatures were reviewed and hypotheses tested. The study therefore, revealed a strong and positive relationship between locus of control and students' academic achievement. Based on the study findings, it was recommended thus:

1) School authorities should learn to reward students with excellent performance by commending good behaviours and excellent performance before other students.

2) Government should also provide the schools with necessary infrastructure that will make teaching and learning very interesting.

3) Parents should provide guidance that will help direct their ward's interest towards high academic achievement irrespective of whether the child is internally or externally controlled. 


\section{Conflicts of Interest}

The authors declare no conflicts of interest regarding the publication of this paper.

\section{References}

[1] Khan, A.S. (2011) Effects of School Systems on Locus of Control. Language in India, 11, 57-64.

[2] Schunk, D.H. (2012) Learning Theories: An Educational Perspective. 6th Edition, Pearson Education Inc., Boston.

[3] Meenu, D. (2016) Factors Affecting the Academic Achievement: A Study of Elementary School Students of NCR Delhi, India. Journal of Education and Practice, 7, 70-75.

[4] Mushtaq, I. and Khan, N.S. (2012) Factors Affecting Students' Academic Performance. Global Journal of Management and Business Research, 12, 17-22.

[5] Ganai, M.Y. and Mir, M.A. (2013) A Comparative Study of Adjustment and Academic Achievement of College Students. Journal of Educational Research and Essays, 1, 5-8.

[6] Saeed, S. and Zyngier, D. (2012) How Motivation Influences Student Engagement: A Qualitative Case Study. Journal of Education and Learning, 1, 252-267. https://doi.org/10.5539/jel.v1n2p252

[7] Hasan, S.S. and Khalid, R. (2014) Academic Locus of Control of High and Low Achieving Students. Journal of Research and Reflections in Education, 8, 22-33.

[8] Rinn, A.N., Boazman, J., Jackson, A. and Barrio, B. (2014) Locus of Control, Academic Self-Concept, and Academic Dishonesty among High Ability College Students. Journal of the Scholarship of Teaching and Learning, 14, 88-114. https://doi.org/10.14434/v14i4.12770

[9] Rotter, J.B. (1966) Generalised Expectancies for Internals versus Externals Control of Reinforcement. Psychological Monographs: General and Applied, 80, 1-28. https://doi.org/10.1037/h0092976

[10] Kalantarkousheh, S.M., Mohagheghi, H. and Hosseini, S.M. (2013) Surveying the Relationship between Locus of Control and Academic Achievement among Students at Allameh Tabataba'i University. International Journal of Physical and Social Sciences, 3, 378-389.

[11] Ghazvini, S. and Khajehpour, M. (2011) Gender Differences in Factors Affecting Academic Performance of High School Students. Procedia-Social and Behavioral Sciences, 15, 1040-1045. https://doi.org/10.1016/j.sbspro.2011.03.236

[12] Bozorgi, S. (2009) On the Relationship between Locus of Control and the Grade Point Average of the Iranian Azad University EFL Students. https://www.researchgate.net>publicationon

[13] Khan, A.S. and Iqbal, N. (2014) Effects of Locus of Control on Gender. Transactions on Education and Social Sciences, 4, 10-12.

[14] Fakeye, D.O. (2011) Locus of Control as a Correlate of Achievement in English as a Second Language in Ibadan. The Journal of International Social Research, 4, 546-552.

[15] Mukolwe, A.N. (2015) Selected Correlates of Examination Anxiety and Academic Performance of Students in Public Secondary Schools in Khwisero Sub-County, Kakamega County, Kenya. An Unpublished Doctorial Thesis, Kenyatta University, 
Nairobi.

[16] Okafor, C.E. (2011) The Role of Vocational and Technical Education in Manpower Development and Job Creation in Nigeria. Journal of Research and Development, 2 , 152-159. 